\title{
Mid to late-Holocene sea-surface temperature variability off north-eastern Newfoundland and its linkage to the North Atlantic Oscillation
}

The Holocene

$1-13$

(C) The Author(s) 2020

Article reuse guidelines:

sagepub.com/journals-permissions DOI: $\mid 0.1$ 177/095968362096|488 journals.sagepub.com/home/hol (9SAGE

\author{
Lisa C Orme, ${ }^{1,2}$ iD Arto Miettinen, ${ }^{2,3}$ Marit-Solveig Seidenkrantz, ${ }^{4}$ (D) \\ Kirsi Tuominen, ${ }^{5}$ Christof Pearce, ${ }^{4}$ Dmitry V Divine, ${ }^{2}$ \\ Mimmi Oksman ${ }^{6}$ and Antoon Kuijpers ${ }^{6}$
}

\begin{abstract}
In recent decades the surface water temperature and salinity in the Labrador Sea have been influenced by atmospheric circulation patterns, such as the North Atlantic Oscillation (NAO), as well as a trend to increasingly warm atmospheric temperatures in recent years. These changes are concerning, given the important role that temperature and salinity have on deep convection in the Labrador Sea. Yet, due to the shortness of available records, the longterm patterns of climate variability in the region are not clear. Here, a diatom-based reconstruction of summer sea-surface temperature (SST) developed from Trinity Bay, Newfoundland, provides insight into variations of SST since $7.2 \mathrm{cal}$ ka BP in the southwestern Labrador Sea. The results show that the Holocene Thermal Maximum (HTM) lasted until c. $5.2 \mathrm{cal}$ ka BP, which was followed by a gradual cooling trend overprinted by centennial temperature fluctuations of $\mathrm{I}-2^{\circ} \mathrm{C}$. Long-term cooling was likely the result of declining Northern Hemisphere orbital summer insolation, potentially amplified by longterm changes in surface and bottom water salinity, which led to a gradual reduction in the stratification of the water column. Centennial fluctuations in temperature vary in-phase with reconstructed variations in the NAO, supporting a consistent relationship between atmospheric circulation and SST over centennial-millennial timescales. Other factors influencing the SST variability may have been solar forcing during the mid-Holocene and variations in the strength of the subpolar gyre during the late-Holocene. The most prolonged cool period at 5.2-4.I cal ka BP coincides with sharply reduced salinity in the Labrador Sea and a weakening of deep ventilation in the northeast Atlantic, highlighting a period with altered ocean surface conditions and circulation across the northern North Atlantic.
\end{abstract}

\section{Keywords}

diatoms, Holocene, Labrador Sea, North Atlantic Oscillation, ocean circulation, sea-surface temperature

Received I3 December 2019; revised manuscript accepted 2 September 2019

\section{Introduction}

The northwest Atlantic Ocean, a domain that extends across 40 $80^{\circ} \mathrm{W}$ and $32-65^{\circ} \mathrm{N}$ and includes the Labrador Sea (Seidov et al., 2016), has experienced significant climate changes in recent decades. The northwest Atlantic has warmed faster than elsewhere in the Atlantic, with a mean sea-surface temperature (SST) increase per decade of $>0.5^{\circ} \mathrm{C}$ (1982-2010; Taboada and Anadón, 2012). In 2012 this region experienced an ocean heat wave that pushed SST $1-3^{\circ} \mathrm{C}$ above the $1980-2011$ mean (Mills et al., 2013). Warming in the Arctic is also having an effect, as freshwater input from the Greenland ice sheet to the Labrador Sea more than doubled between 2000 and 2010 compared to the period 1958-2000 (Bamber et al., 2012). These changes have raised concerns about possible future reductions in deep water formation in the Labrador Sea, as warmer and fresher surface waters have low density and slow down deep convection, with possible implications for the strength of the Atlantic Meridional Overturning Circulation (Böning et al., 2016; Robson et al., 2016; Yang et al., 2016).

Atmospheric temperatures over the Labrador Sea and surrounding landmasses including Newfoundland are influenced by atmospheric circulation associated with the North Atlantic Oscillation (NAO), the major mode of atmospheric variability in the
North Atlantic region (Banfield and Jacobs, 1998; Hurrell and Van Loon, 1997). When there is a positive NAO the storm track across the North Atlantic strengthens and has a southwest to northeast orientation (Hurrell, 1995), allowing frequent cold air outbreaks from the Canadian Arctic towards the Labrador Sea (Kolstad et al., 2009) and a drier and cooler climate across

'ICARUS, Department of Geography, Maynooth University, Maynooth, Ireland

${ }^{2}$ Norwegian Polar Institute, Fram Centre, Tromsø, Norway

${ }^{3}$ Ecosystems and Environment Research Programme, University of Helsinki, Helsinki, Finland

${ }^{4}$ Palaeoceanography and Paleoclimate Group, Arctic Research Centre, and iClimate, Department of Geoscience, Aarhus University, Aarhus, Denmark

${ }^{5}$ Department of Geosciences and Geography, University of Helsinki, Helsinki, Finland

${ }^{6}$ Geological Survey of Denmark and Greenland, Copenhagen, Denmark

\section{Corresponding author:}

Lisa C Orme, Department of Geography, Maynooth University, Laraghbryan House, Maynooth, W23 TN90, Ireland.

Email: lisa.orme@mu.ie 
Greenland, the Labrador Sea and Newfoundland (Banfield and Jacobs, 1998; Hurrell and Van Loon, 1997). A negative NAO meanwhile is associated with a more northerly storm track over the northwest Atlantic and less cold air advected from the north, causing the Labrador Sea region to experience a warmer and wetter climate (Hurrell and Van Loon, 1997). As a result, on Newfoundland there was a significant negative correlation between the NAO and winter atmospheric temperature over the period 1895-1995 (Banfield and Jacobs, 1998). Nevertheless, while the NAO is the dominant mode of atmospheric pressure variability in the North Atlantic, research has shown that since 1950 AD this was evident just $47 \%$ of the time (Hurrell and Deser, 2010), supporting that other modes of atmospheric circulation, such as atmospheric blocking, can also have an influence on the climate of this region (Häkkinen et al., 2011; Pfahl and Wernli, 2012).

On the Newfoundland shelf SST is altered by ocean-atmosphere heat fluxes and wind-driven advection of colder water to the region by the Labrador Current (LC), which are both often controlled by atmospheric circulation variability related to the NAO (Banfield and Jacobs, 1998; Dickson et al., 1996; Prinsenberg et al., 1997; Umoh et al., 1995). For example, deepening of the Icelandic Low, when the NAO is positive, causes strengthened northerly airflows across the Labrador Sea, which promotes cooler atmospheric temperatures, heat loss from the ocean, and a stronger LC with increased transport of cold water southwards (Agnew, 1993; Deser et al., 2002; Flatau et al., 2003; Han et al., 2010; Prinsenberg et al., 1997). Furthermore, sea ice extent and thickness are enhanced on the Newfoundland shelf, as lower temperatures and stronger northerly winds promote local ice formation and sea ice advection (Prinsenberg et al., 1997). The variability of the NAO has also been linked with variations in Labrador Sea deep convection, as occurred during the early 1990s when a strong Icelandic Low pressure system situated over the northern Atlantic resulted in high wind stress and low temperatures that enhanced overturning rates (Dickson et al., 1996; Khatiwala et al., 2002; Robson et al., 2016).

Multi-decadal modulation of ocean temperature around Newfoundland and across the North Atlantic also occurs at timescales of 55-80 years, in a phenomenon called the Atlantic Multidecadal Oscillation (AMO; Kerr, 2000; Loder and Wang, 2015). Some research has suggested that the AMO is a response to decadal climate variability associated with the NAO, as wind and buoyancy forcing over the North Atlantic alters the strength of northward heat transport (McCarthy et al., 2015; Sun et al., 2015), while others suggest it is linked to interval variability of the ocean circulation system (Knudsen et al., 2011), at times modified by solar irradiation (Knudsen et al., 2014).

The salinity of the Labrador Sea meanwhile has been shown to result from variations in freshwater input from a number of sources, including precipitation, meltwater from the Greenland ice sheet and Canadian glaciers, and the oceanic transport of freshwater and sea ice to the region (Bamber et al., 2012; Yang et al., 2016), as well as the transport of salt from lower latitudes modulated by the subpolar gyre vigor (Thornalley et al., 2009). Periodically, the area has experienced Great Salinity Anomalies when large volumes of freshwater have been advected from the Arctic into the North Atlantic, including the Labrador Sea (Belkin et al., 1998; Haak et al., 2003).

By reconstructing past variability of temperature and salinity from the Labrador Sea, we can further increase our understanding of the natural patterns and drivers, such as the oceanic response to centennial-scale variability of atmospheric circulation and enhanced freshwater input. Existing palaeoclimate records from the Newfoundland region of the Labrador Sea include qualitative and quantitative SST records from dinoflagellate cysts (de Vernal and Hillaire-Marcel, 2006; Sheldon et al., 2015; Solignac et al., 2011), qualitative benthic foraminifera-based records reflecting bottom water temperature (Sheldon et al., 2015; 2016) and dinocyst-based salinity reconstructions (de Vernal and Hillaire-Marcel, 2006). In the eastern Labrador Sea region off West Greenland there are diatom transfer function-based sea-ice estimates (Sha et al., 2016, 2017) and qualitative records of diatom assemblages (Ren et al., 2009; Seidenkrantz et al., 2007b; Sha et al., 2012). However no quantitative diatom-based SST estimates exist from the south-western Labrador Sea to provide additional, independent evidence of SST during the Holocene to complement the existing dinocyst-based SST records (de Vernal and Hillaire-Marcel, 2006).

Here we present a diatom-based SST reconstruction from Trinity Bay, located on the northeast coast of Newfoundland at the south-western margin of the Labrador Sea spanning the period 7.2-0.1 cal ka BP (hereafter ka BP). Valuable palaeoclimate records spanning the Holocene have previously been developed from Trinity Bay and Bonavista Bay on the north coast of Newfoundland and Placentia Bay on the south coast, using a range of proxy methods to infer bottom and surface water temperatures and salinities, sea ice presence and exotic pollen influx (Jessen et al., 2011; Sicre et al., 2014; Sheldon et al., 2015, 2016; Solignac et al., 2011). While SST around Newfoundland has been quantitatively estimated over the last 2000 years (Sicre et al., 2014), this study for the first time provides a quantitative SST record for Newfoundland spanning the mid to late-Holocene.

\section{Oceanographic setting of the study area}

Trinity Bay is located on the northeast coast of Newfoundland adjacent to the south-western Labrador Sea (Figure 1). It is approximately $100 \mathrm{~km}$ long and $30 \mathrm{~km}$ wide with a maximum depth of $590 \mathrm{~m}$ (Yao, 1986). The modern-day oceanography of Trinity Bay is mostly controlled by the Inner Labrador Current, which is the inshore branch of the main Labrador Current that passes to the north east of the Newfoundland coast (Petrie and Isenor 1985). The Labrador Current is a mixture of polar waters from the Baffin Current, warmer waters from the West Greenland Current, and cool and less saline water outflow from the Hudson Strait, with the colder and less saline waters dominating the inner branch. It thus carries cold water of relatively low salinity southwards (Drinkwater, 1996), meeting the warm Gulf Stream to the south of Newfoundland. During summer, Trinity Bay is stratified, with a pycnocline at $\sim 25 \mathrm{~m}$ depth and an observed freshening of the surface waters towards the mouth of the bay (Yao, 1986).

St. John's Station (east Newfoundland, Figure 1) is located at the town of St. John's. It has a monthly surface air temperature record extending back to 1942, which shows summer (JJAS) temperatures of $12-14^{\circ} \mathrm{C}$ (Banfield and Jacobs, 1998). Summer (JJAS) temperatures were on average $13.3^{\circ} \mathrm{C}$ between 1942 and 1997 but increased to an average of $14.4^{\circ} \mathrm{C}$ between 1998 and 2010 (Supplementary Information 1). Winter (NDJF) atmospheric temperatures have shown greater decadal variability, with warmer intervals at 1950-1970 and 1996-2010 and a colder interval from 1970 to 1995 , which correspond with periods with more negative and positive NAO circulation respectively (Supplementary Information 1) and with periods when the AMO was positive and negative respectively (Trenberth and Shea, 2006).

Monthly SST measurements taken since 1951 from Ocean Station 27 (Figure 1), which is located $5 \mathrm{~nm}(8 \mathrm{~km})$ east off Newfoundland and within the Inner Labrador Current, shows a large seasonal range of $\sim 13^{\circ} \mathrm{C}$ (Umoh et al., 1995). The summer season is characterised by a rapid warming from May to August as SST increases on average from $0^{\circ} \mathrm{C}$ to $12^{\circ} \mathrm{C}$, before subsequently cooling in autumn and winter (Petrie et al., 1991). The average modern August SST (measured between 1946 and 1995) is $12.5^{\circ} \mathrm{C}$ within the upper $\sim 1-10 \mathrm{~m}$, below which there is a steep 


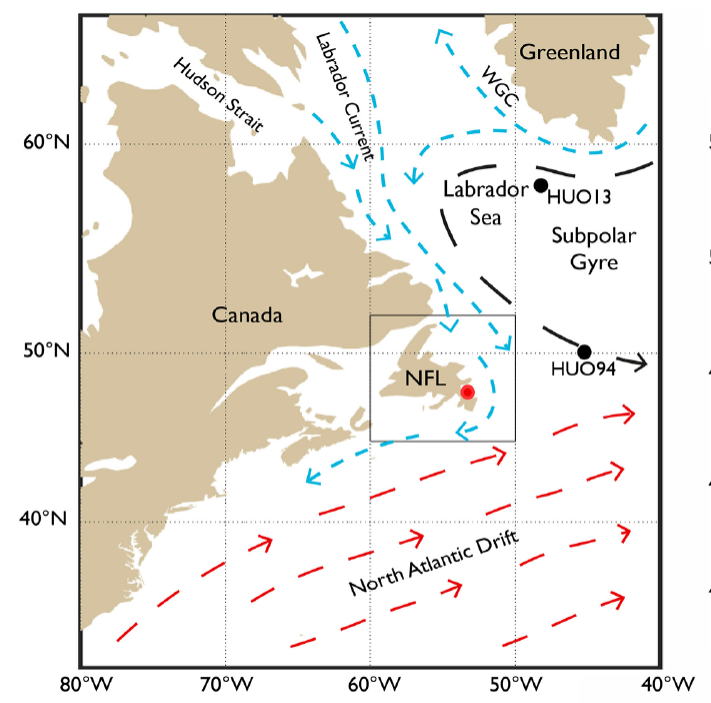

(a)

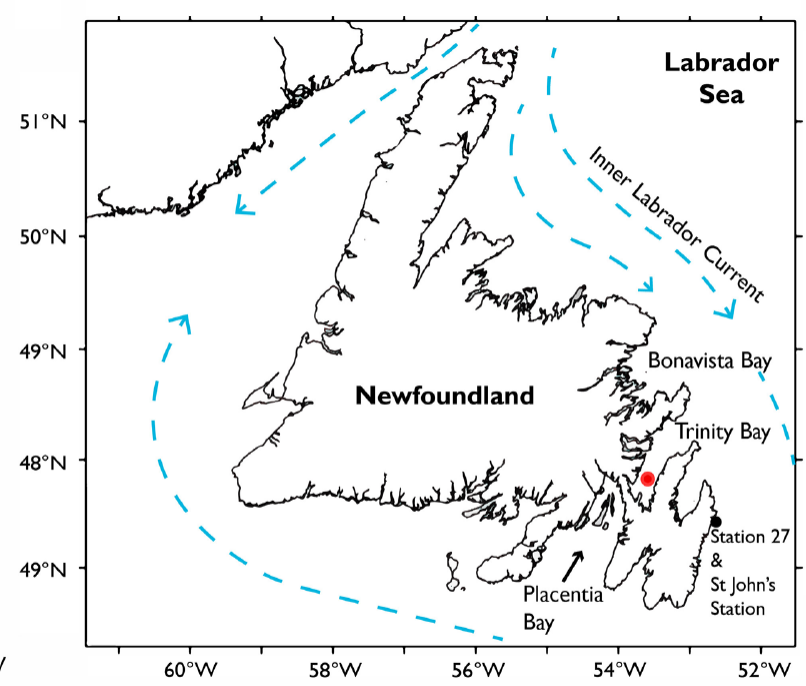

(b)

Figure I. Location of core AI07-06G in Trinity Bay, Newfoundland. (a) Location of Newfoundland and Trinity Bay (red dot) in the northwest Atlantic and ocean circulation patterns. Black dots show the locations of core sites HU90-0I3-0I3PC on the southwest Greenland Rise (HU0I3) and HU9I-045-094PC on the Orphan Knoll (HU094) where salinity reconstructions have been developed (de Vernal and HillaireMarcel, 2006). Red arrows show warm surface waters, blue arrows show cold surface currents and black arrows show the subpolar gyre circulation. The position of the West Greenland Current and Labrador Current are shown. (b) Location of core AI07-06G (red dot) in Trinity Bay, meteorological and hydrological stations (St. John's Station and Station 27) and the location of other bays mentioned in the text.

thermocline, with temperatures of $0-1{ }^{\circ} \mathrm{C}$ at $50 \mathrm{~m}$ depth (Banfield and Jacobs, 1998; Petrie et al., 1991).

Sea ice is transported to Newfoundland by the Labrador Current, with mean December-March sea ice concentrations on the northern coast ranging between $5 \%$ and $45 \%$ during the period 1953-1997, with strong decadal variability (Deser et al., 2002). The maximum sea ice extent on the northeast Newfoundland shelf occurs in February to March, with ice usually present between December and June (Prinsenberg et al., 1997). In Trinity Bay during the period 1981-2010 sea ice was present in February to March in $15 \%-33 \%$ of years (Canadian Ice Service, 2020), with most ice blown into the bay rather than forming in situ (Fisheries and Oceans Canada, 2012; Sheldon et al., 2015).

Salinity measurements from Station 27 show that waters deeper than $150 \mathrm{~m}$ have relatively high salinities $(\sim 33 \mathrm{psu})$ and are overlain by water with lower salinity (31-33 psu) (Myers et al., 1990). The surface water salinity varies seasonally, from a salinity maxima of 32.4 psu in March to a minima of 31 psu in September to October, while the salinity of the deeper water (below $150 \mathrm{~m}$ ) varies less, remaining at approximately 33 psu throughout the year, resulting in a more stratified water column during the summer to autumn months (Myers et al., 1990). This freshening of the surface waters during summer and early autumn is thought to originate from meltwater and runoff entering the sea from Hudson Bay and ice melt over the Labrador and Newfoundland shelves (Myers et al., 1990).

\section{Material and methods}

\section{Material}

The $431 \mathrm{~cm}$ long sediment core AI07-06G was recovered from Trinity Bay, north-eastern Newfoundland $\left(47.85^{\circ} \mathrm{N}, 53.58^{\circ} \mathrm{W}\right)$ in 2007 by the Russian research vessel Akademik Ioffe using a gravity corer (Seidenkrantz et al., 2007a). The core was taken from one of the deepest parts of Trinity Bay at a water depth of $511 \mathrm{~m}$ (Figure 1). The core was split in half lengthwise and stored at $2{ }^{\circ} \mathrm{C}$. Previous analysis on the core includes X-ray fluorescence (XRF) core scanning and analysis of benthic foraminifera and dinoflagellate cyst assemblages (Sheldon et al., 2015). The sediment lithology has been described by Sheldon et al. (2015), who

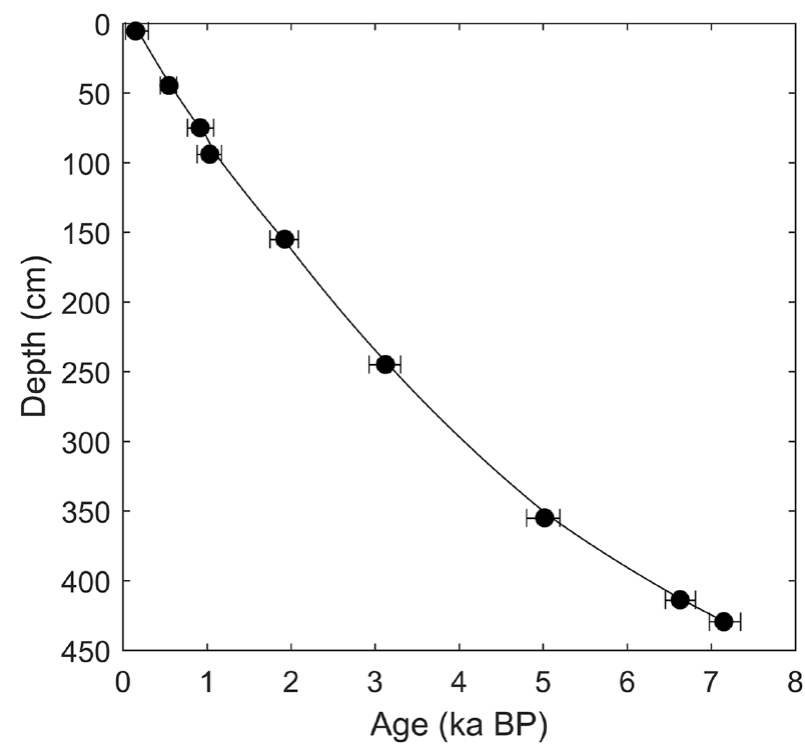

Figure 2. Age-depth model for core AI07-06G. The continuous line is the modelled chronology (mean age) through the core and the points show the calibrated radiocarbon dates, with error bars representing the modelled $95 \%$ confidence range, as published in Sheldon et al. (2015).

identified that the core consists of laminated dark/olive grey clay with some fine silt.

\section{Chronology}

The development of the chronology is described in full by Sheldon et al. (2015) and is presented in Figure 2. The $431 \mathrm{~cm}$ long core has been dated by nine AMS radiocarbon dates obtained from calcareous benthic foraminifera. The radiocarbon dates were calibrated using a marine reservoir offset $\Delta \mathrm{R}$ of $139 \pm$ 61 years (Sheldon et al., 2015; Solignac et al., 2011) and the Marine13 calibration dataset (Reimer et al., 2013). The age-depth model was developed in Oxcal version 4.2 using a $\mathrm{P}_{-}$sequence depositional model (Ramsey, 2008). 


\section{Diatom analysis and SST reconstruction}

Planktonic diatoms are good indicators of SST in the high-latitude oceans (Andersen et al., 2004; Jiang et al., 2005; Koç Karpuz and Schrader, 1990), because they live in the uppermost surface waters $(0-50 \mathrm{~m})$ and the optimum temperatures for different species are distributed along a linear temperature gradient, allowing SST to be estimated from fossilised species assemblages (Berner et al., 2008; Birks, 1998). Core AI07-06G was analysed for diatoms at $3 \mathrm{~cm}$ intervals in the section $100-431 \mathrm{~cm}$ and at $10 \mathrm{~cm}$ intervals in the section $0-100 \mathrm{~cm}$. The diatom samples were prepared using the method described by Koç et al. (1993), which consists of treatment with $\mathrm{HCl}$ and $\mathrm{H}_{2} \mathrm{O}_{2}$ to remove calcium carbonate and organic matter, clay separation and preparation of slides. A Leica Orthoplan microscope with $1000 \times$ magnification was used to identify and count the diatoms. The counting procedure described by Schrader and Gersonde (1978) was followed. A minimum of 300 diatom valves were identified for each sample. Diatom taxonomy is in accordance with Pearce et al. (2014).

To convert diatom counts to quantitative SST estimates a transfer function-based approach was used. A calibration dataset has been developed, which consists of the measured relative abundance of 52 diatom species in 183 surface sediment samples from the North Atlantic, the Labrador Sea, the Nordic Seas and Baffin Bay at locations where the modern SST is known (Miettinen et al., 2015). The weighted averaging partial least squares (WA-PLS) transfer function (ter Braak and Juggins, 1993) was then used to convert the diatom counts for AI07-06G samples to SST estimates, based on the relationship between modern ocean temperature at $10 \mathrm{~m}$ depth and diatom assemblage. August was chosen as a target month for the SST reconstruction, because for diatom transfer functions August SST (aSST) gives the best match with respect to observed SST (Berner et al., 2008; Miettinen, 2018; Miettinen et al., 2015). The derived 2-component WA-PLS diatom aSST transfer function has a root mean square error of prediction (RMSEP) of $1.1^{\circ} \mathrm{C}$, a coefficient of determination between observed and inferred values $\left(\mathrm{r}^{2}\right)$ of 0.92 , and a maximum bias of $2.8^{\circ} \mathrm{C}$ (Oksman et al., 2017). The RMSEP for the reconstructed aSST was estimated using the $h$-block cross validation technique (Trachsel and Telford, 2016) to allow for spatial dependency in the calibration data, which can lead to underestimation of the prediction error because of pseudo-replication.

\section{Factor analysis}

Q-mode factor analysis (Imbrie and Kipp, 1971) of diatom composition in marine sediments is a useful tool to characterise past oceanographic conditions, in terms of showing variations in the prevalent surface water masses (Andersen et al., 2004; Berner et al., 2011; Orme et al., 2018). Q-mode factor analysis has been applied to the modern diatom calibration dataset of surface sediment samples from the North Atlantic to group the diatom taxa into a number of assemblages (or factors) that are indicative of specific environmental conditions and hence related to distinct ocean water masses (Andersen et al., 2004; Oksman et al., 2017). The eight identified factors are the Arctic Greenland Assemblage (factor 1), North Atlantic Assemblage (factor 2), sub-Arctic Assemblage (factor 3), Norwegian Atlantic Current Assemblage (factor 4), Sea Ice Assemblage or Marginal Ice Zone (MIZ) assemblage (Oksman et al., 2017; factor 5), Arctic Assemblage (factor 6), East and West Greenland Current Assemblage (factor 7), and the Mixed Water Masses Assemblage (factor 8). A matrix of down-core diatom assemblages from core AI07-06G is then projected on the matrix of derived modern factors (Oksman et al., 2017) to describe the composition of past assemblages in terms of these factors, which reflect the spatial distribution of modern surface water masses. The adequacy of the decomposition is assessed by the commonality, a measure of the fraction of total variance of a specific sample represented by the combination of factors.

\section{Spectral analysis}

Palaeoclimate time series often exhibit red noise characteristics that can be modelled by a first order autoregressive (AR1) process. To establish whether quasi-periodic variability existed throughout the aSST record, REDFIT spectral analysis (Schulz and Mudelsee, 2002) was carried out. This is a suitable method as it has been designed for unevenly spaced, paleoclimate data, therefore avoiding the need to resample and interpolate the data, which can introduce bias (Schulz and Mudelsee, 2002). The analysis was conducted using the REDFIT tool in the PAST 3.25 software (Hammer et al., 2001) using the Welch window with two overlapping segments. The appropriateness of the AR1 model to describe the analysed data was tested using a nonparametric runs test (Bendat and Piersol, 1986) embedded in the package. The significance of the generated spectrum is assessed using the $90 \%$ and $95 \%$ false alarm levels. These indicate the maximum spectral amplitude that would be expected if the dataset was generated by an AR1 process and as such peaks exceeding these levels show non-AR1 variability that can be considered significant (Schulz and Mudelsee, 2002).

We further use the wavelet transform-based technique for bandpass filtering and visualization of the quasiperiodic behaviour of the analysed records (Torrence and Compo, 1998). As a basic function the Morlet wavelet is used, which provides a good balance between time and frequency localisation for features in a spectrum. Prior to filtering, the record was resampled using spline interpolation to a new timescale with a regular time increment of 10 years.

\section{Results}

The AI07-06G diatom abundance and aSST records have an average temporal resolution of 60 years between 1.18 and $7.18 \mathrm{ka} \mathrm{BP}$ and an average temporal resolution of 100 years between 1.18 and $0.13 \mathrm{ka} \mathrm{BP}$ (Figure 3). The diatom assemblage of core AI07-06G (Figure 3) is dominated by Thalassiosira antarctica var. borealis resting spores, Bacterosira bathyomphala resting spores, and Thalassionema nitzschioides. There are smaller percentage abundances of Porosira glacialis, Fragilariopsis oceanica, Rhizosolenia hebetata f. semispina, Thalassiosira nordenskioeldii, Shionodiscus trifultus and Shionodiscus oestrupii among others.

Three zones can be identified in the diatom assemblage record (Figure 3). Zone 1 from 7.2-5.2 ka BP is characterised by higher abundances of T. nitzschioides and Rh. hebetata f. semispina and lower abundances of $T$. antarctica var. borealis spores and $B$. bathyomphala spores. Zone 2 from 5.2 to $1.2 \mathrm{ka} \mathrm{BP}$ has higher abundances of T. antarctica var. borealis spores and B. bathyomphala spores, slightly elevated abundances of $P$. glacialis and $F$. oceanica and lower abundances of Rh. hebetata f. semispina and T. nitzschiodes. Zone 3 from 1.2 to $0.1 \mathrm{ka} \mathrm{BP}$ has a prominent increase in sea ice related species $F$. oceanica, P. glacialis and Actinocyclus curvatulus, and decreases in T. nitzschioides, S. oestrupii and T. antarctica var. borealis spores.

Factor analysis on core AI07-06G (Figure 4) reveals that the down core diatom composition during most of the covered period is dominated by Factor 6, the Arctic water assemblage, with loadings of 0.7 to 0.8 . This factor in the North Atlantic is associated with intermediate/mixed water masses and highest loadings are found in modern surface sediments from Baffin Bay and in the Nordic Seas under the East Icelandic Current and the Jan Mayen Polar Current (Andersen et al., 2004; Oksman, et al., 2017). In the AI07-06G record there are intervals with lower weightings of Factor 6 at $6.8,6.1,5.3,3.7$ and 0.3 ka BP. During shorter time periods two other factors demonstrate a significant contribution to the overall diatom composition, revealing intermittent influence from other water masses in the study area. Factor 4 is representative of relatively warm and saline waters of the Norwegian Atlantic current (Andersen et al., 2004; Oksman, et al., 2017) and 


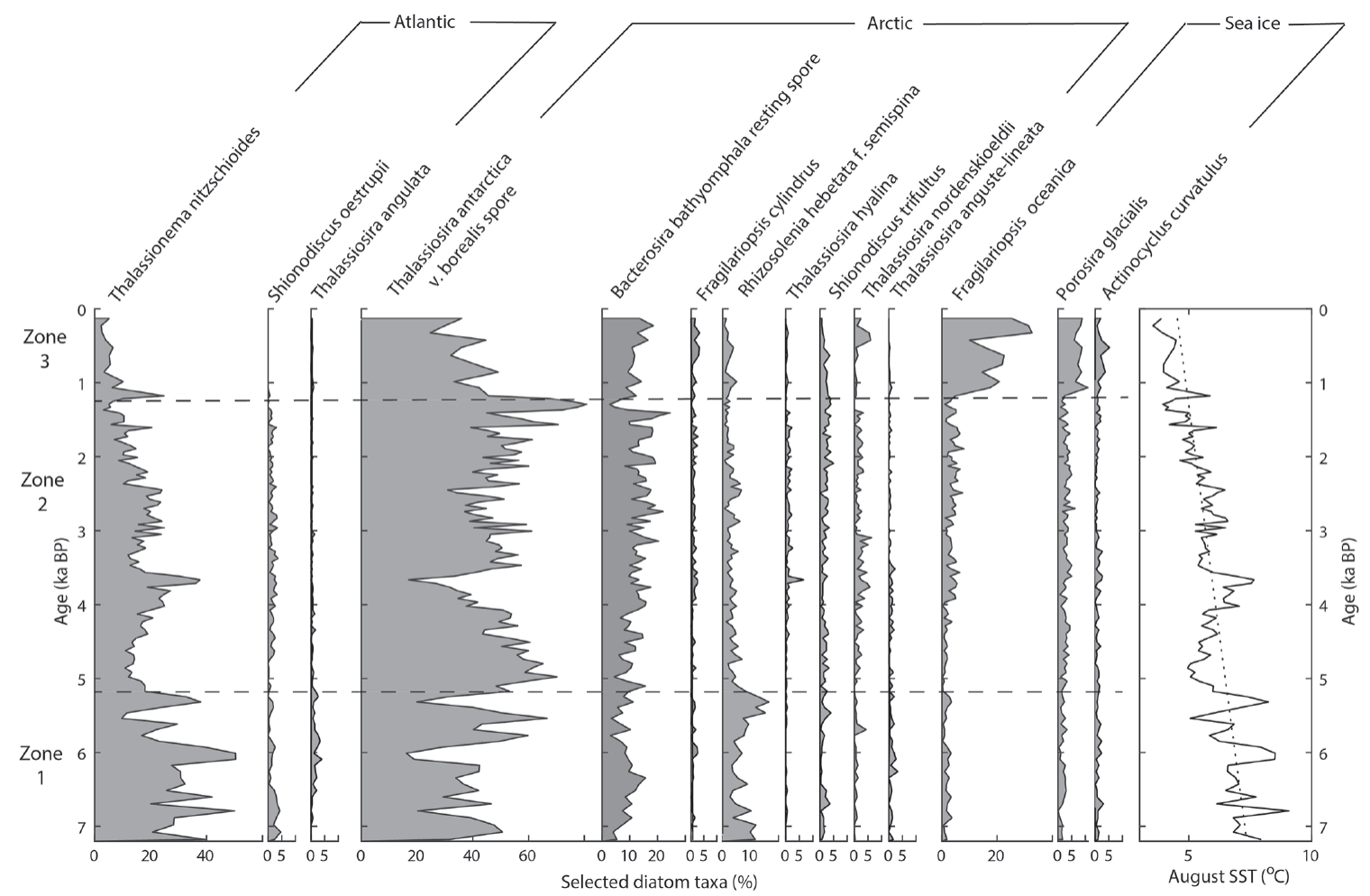

Figure 3. Core AI07-06G diatom abundances of the most common diatom species as percentages of total sample and reconstructed aSST (right), including trendline (dotted line).

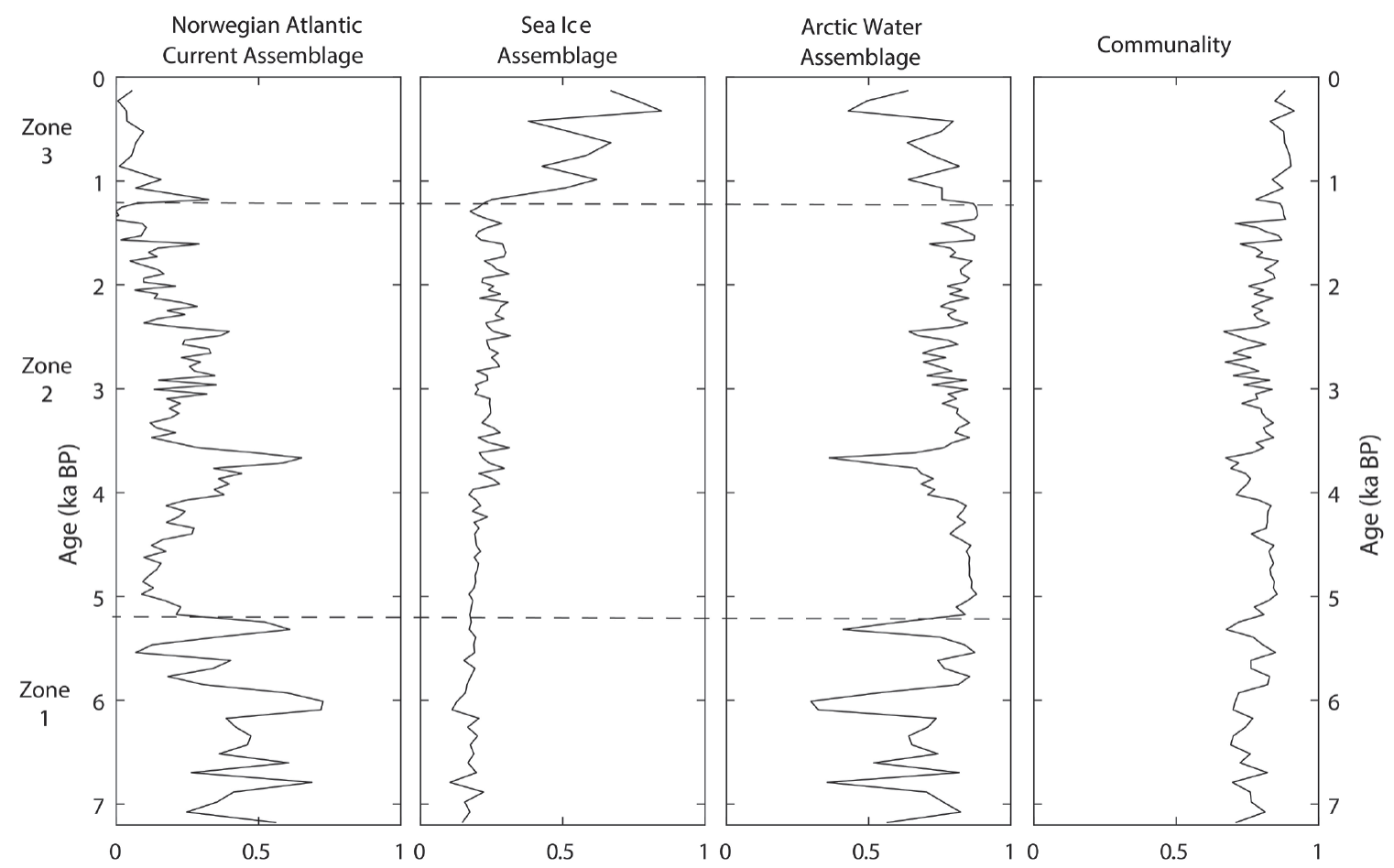

Figure 4. Results of the Q-mode factor analysis showing the variability through time of the factor loadings for the three main assemblages in the diatom record from core AI07-06G. From left: factor 4 (Norwegian Atlantic Current assemblage), factor 5 (Sea ice or Marginal Ice Zone assemblage) and factor 6 (Arctic water assemblage). Communality, or the fraction of total variance accounted for by factor decomposition, is displayed in the right panel. Zones are defined based on the diatom abundances in Figure 3.

shows higher loadings in Zone 1 of the record until c. $5.9 \mathrm{ka} \mathrm{BP}$, with later peaks at c. 5.3 and $3.7 \mathrm{ka} \mathrm{BP}$, followed by a gradual reduction. The diatom assemblage associated with Factor 5 (Marginal Ice Zone assemblage) shows a steadily increasing contribution through the Holocene with a more significant loading after $\mathrm{c}$. $1.2 \mathrm{ka} \mathrm{BP}$, coinciding with Zone 3 . High values of the communality index (0.7-0.9) through the record support that the fossil assemblages were similar to the modern assemblages as revealed by the factor analysis.

The average reconstructed aSST for the period 7.18-0.13 ka $\mathrm{BP}$ was $5.8^{\circ} \mathrm{C}$ (range $3.5-9^{\circ} \mathrm{C}$ ). The aSST reconstruction shows a cooling trend of approximately $0.4^{\circ} \mathrm{C} / 1000$ years through the record (Figure 3). This is associated with an increasing abundance of cold water and sea-ice associated Arctic species, such as 
T. antarctica var. borealis spores, $B$. bathyomphala spores, $S$. Trifultus, P. glacialis, F. oceanica and A. curvatulus, which have optimum August temperatures of 4.9, 4.6, 4.4, 4.3, 3.6 and $4.7^{\circ} \mathrm{C}$ respectively based on the used calibration dataset (Oksman et al., 2019) and decreasing abundance of warmer Atlantic species $T$. nitzschioides, with an optimum August temperature of $16^{\circ} \mathrm{C}$.

Centennial-scale fluctuations in temperature superimposed on the cooling trend are pronounced and generally above the RMSEP of $1.1^{\circ} \mathrm{C}$ (Figures 3 and $6 \mathrm{c}$ ). The intervals with $1-2^{\circ} \mathrm{C}$ of warming occurred at c. $6.8,6.1-5.9,5.4-5.2$ and $4.1-3.6 \mathrm{ka}$ BP with a minor warming of $<1{ }^{\circ} \mathrm{C}$ at $\sim 3-2.4 \mathrm{ka} \mathrm{BP}$. Intervals with $1-1.5^{\circ} \mathrm{C}$ cooler temperatures occurred at c. 5.5, 5.2-4.1, 1.3-1.2 and 1-0 $\mathrm{ka}$ BP with a minor cooling of $<0.5^{\circ} \mathrm{C}$ at $3.6-3.1 \mathrm{ka}$ BP. These fluctuations are associated with variations in the relative abundance of the two dominant species, with warm/cold periods having a lower/higher abundance of Arctic species T. antarctica var. borealis spores and higher/lower abundance of Atlantic species $T$. nitzschioides. The temperature fluctuations are of larger magnitude in the earlier part of the record, with a change at approximately $3.6 \mathrm{ka}$ BP to lower magnitude temperature variability. Spectral analysis conducted on the detrended aSST data using the REDFIT method showed quasi-periodic variability of $\sim 800$ years, significant above the $95 \%$ false alarm level, with cycles of 2350 and 340 years significant above the $90 \%$ level (Figure 5).

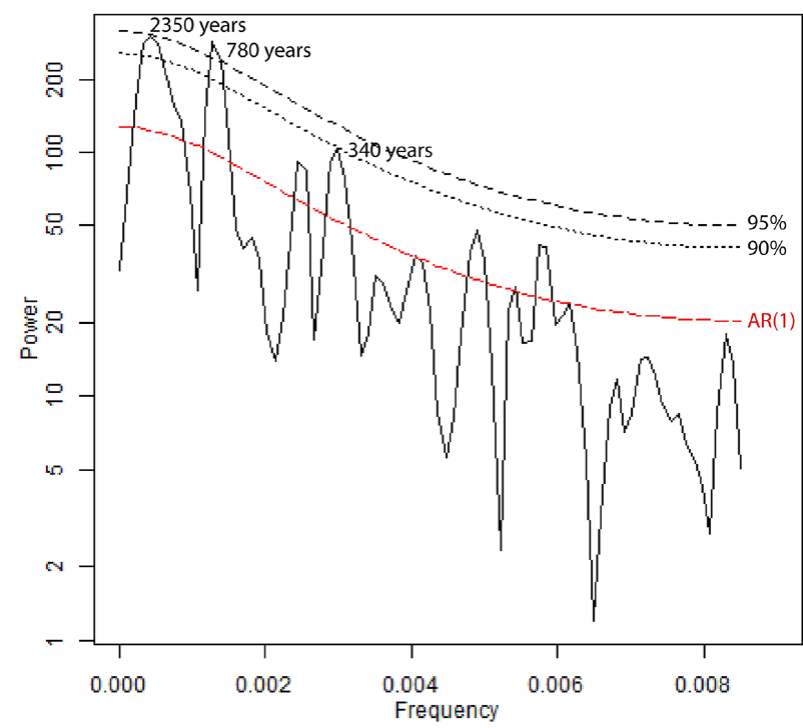

Figure 5. REDFIT spectral density estimate of analysis of the detrended core AI07-06G aSST reconstruction (solid black line) and the theoretical red-noise spectrum (dashed red line). Dashed and dotted black lines show the $95 \%$ and $90 \%$ Chi2 'false alarm' levels, respectively.

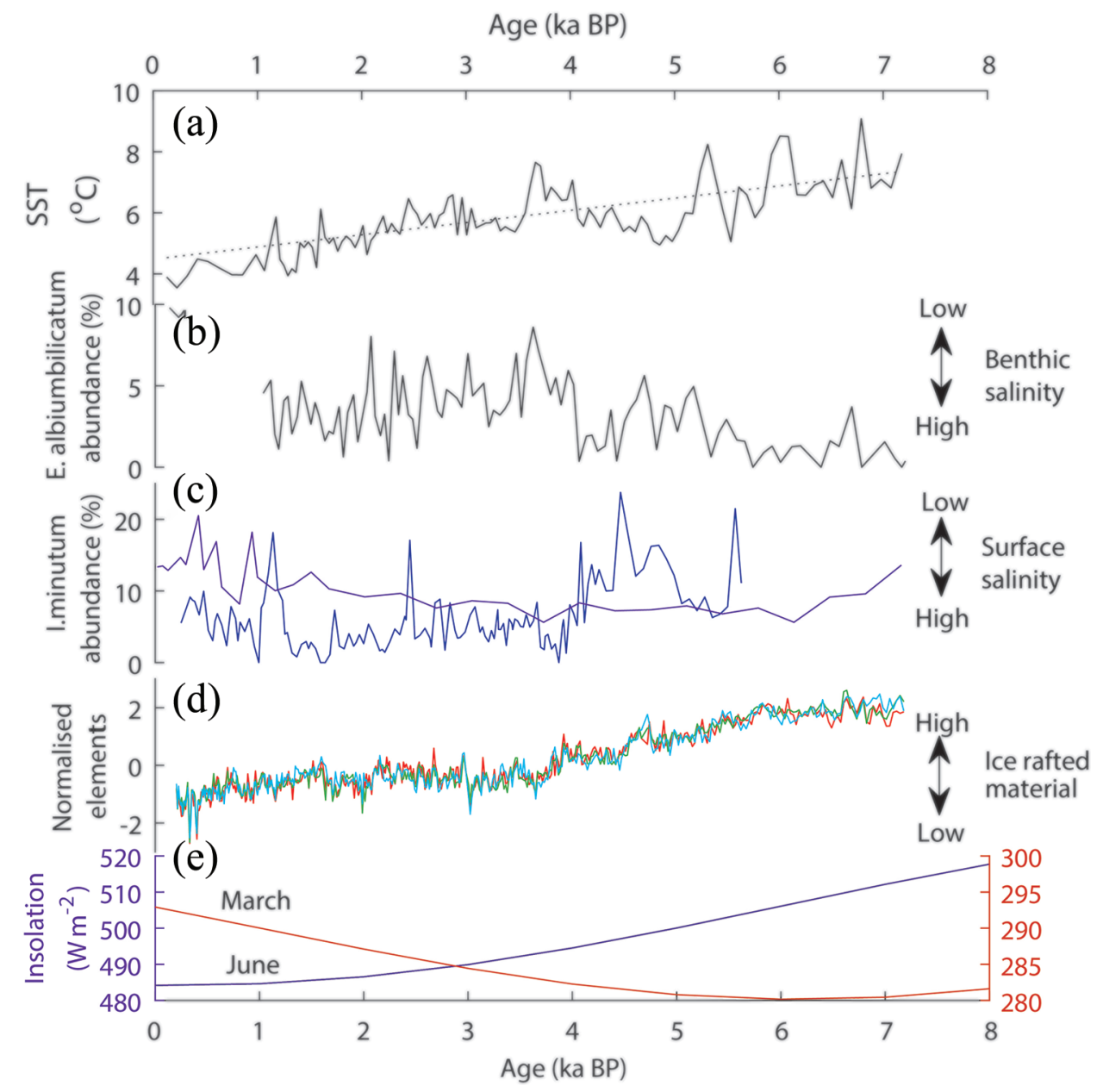

Figure 6. Millennial trends and forcings in Trinity Bay. (a) Core AI07-06G diatom-based SST reconstruction from Trinity Bay (this study). (b) Benthic salinity in Trinity Bay core A107-06G inferred from variations in benthic foraminifera E. albiumbilicatum abundance (Sheldon et al., 20I5). (c) Abundance of dinocyst I. minutum in Trinity Bay (core Al07-06G; Sheldon et al., 20I5; purple line) and Bonavista Bay (core Al0703G; Solignac et al., 20I I: blue line). (d) Normalised element (XRF) concentrations interpreted as a proxy for ice-rafted material (Fe = blue, $\mathrm{Ti}=$ red, $\mathrm{K}=$ green; Sheldon et al., 20I5). (e) Holocene changes in insolation at $48^{\circ} \mathrm{N}$ during summer (June, purple line) and spring (March, red line) based on Berger and Loutre (1991). 


\section{Discussion}

\section{Regional sea-surface temperature and salinity trends}

Modern versus reconstructed aSST. The reconstructed aSST of $\sim 4^{\circ} \mathrm{C}$ in the uppermost samples from core AI07-06G is cooler than the modern August temperature of $\sim 12^{\circ} \mathrm{C}$ in the surface $10 \mathrm{~m}$ as measured at Station 27 between 1946-1995 (Banfield and Jacobs, 1998) but similar to the reconstructed alkenone-based $\mathrm{SST}$ of $5-6^{\circ} \mathrm{C}$ over the last 2000 years measured in Bonavista Bay (Sicre et al., 2014). A probable reason for the difference with the observed surface temperature is that diatoms dwell within the upper $50 \mathrm{~m}$ of the water column, and in this region modern summer temperatures span a large range of $0-12^{\circ} \mathrm{C}$ in the upper $50 \mathrm{~m}$ (Banfield and Jacobs, 1998). At Station 27 the average temperature of the upper $50 \mathrm{~m}$ during August was $6.5^{\circ} \mathrm{C}$ between 1999 and 2016 (Supplementary Information 2), supporting that the diatom-based aSST reconstruction from core AI07-06G likely reflects the average temperature of the upper $50 \mathrm{~m}$. An additional factor potentially explaining the slightly low reconstructed aSST is the high degree of seasonality in SST on the Newfoundland Shelf. While statistical analysis of the North Atlantic diatom calibration dataset shows that reconstructed SST has the strongest similarity with August SST (Berner et al., 2008; Miettinen, 2018; Miettinen et al., 2015), diatom blooms occur during a longer period through the spring and summer (Von Quillfeldt, 2000). As Newfoundland has a highly seasonal climate, with an increase in surface SST of $12^{\circ} \mathrm{C}$ from March to August measured at Station 27 (Petrie et al., 1991), the presence of diatoms suited to both cooler and warmer waters in different months potentially contributed to low reconstructed August SST estimates.

Millennial temperature trends. The entire studied section from 7.2 to $0.1 \mathrm{ka}$ BP is characterised by an overall summer surface water cooling trend, as aSST in Trinity Bay gradually decreased by approximately $3^{\circ} \mathrm{C}$ (as shown by the trendline in Figure 6a). This is also evident in long term changes in factor loadings (an increasing sea ice assemblage and declining Norwegian Atlantic Current assemblage; Figure 4), and trends in the associated abundances of specific diatoms (e.g. a decreasing abundance of warmer Atlantic species T. nitzschioides; Figure 3).

The long-term cooling trend is in contrast to the evidence from some qualitative dinoflagellate cyst (hereafter dinocyst) reconstructions from Bonavista Bay and Placentia Bay, Newfoundland, which suggest that there was instead a sea-surface warming after $4 \mathrm{ka}$ BP (Solignac et al., 2011), while the dinocyst record from our core AI07-06G from Trinity Bay shows a cooling only occurred after $2.1 \mathrm{ka}$ BP (Sheldon et al., 2015). However, a warm mid-Holocene followed by a gradual cooling has been shown in many other reconstructions from the region; including pollen and palaeolimnological records from Newfoundland reflecting atmospheric temperatures (Brown MacPherson, 1995; Finkenbinder et al., 2016) and pollen-based reconstructions of North American July temperatures (Viau et al., 2006). SST reconstructions (based on alkenones, dinoflagellate cyst assemblages and $\mathrm{Mg} / \mathrm{Ca}$ and $\delta^{18} \mathrm{O}$ measurements on planktonic foraminifera) from the south of Newfoundland (Keigwin et al., 2005; Sachs, 2007) and the Orphan Knoll to the east (de Vernal and Hillaire-Marcel, 2006; Hoogakker et al., 2015) also show a long term cooling, with the consistency between different proxies supporting that the cooling was a feature of both annual and seasonal temperature. Multi-proxy compilations of temperature records from the eastern Canadian Arctic and north and east Greenland also show strong warming at approximately 7-5 ka BP followed by cooling (Briner et al., 2016; Gajewski, 2015). The cooling trend is therefore present in reconstructions reflecting local and regional atmospheric and ocean temperatures.
In Trinity Bay the long term cooling trend culminated in an enhanced presence of sea ice during the last $1.2 \mathrm{ka} \mathrm{BP}$, as indicated by increased abundances of sea ice-associated diatoms (Figure 3) and higher loading of the Sea Ice factor (Figure 4). Lower temperatures may have led to the in-situ formation of sea ice, while enhanced advection of sea ice to Newfoundland via the Labrador Current is also possible, as some evidence supports that sea ice along the west coast of Greenland increased after c. 1.5 to 1.2 ka BP (Moros et al., 2016; Seidenkrantz et al., 2007b; Sha et al., 2017).

Insolation forcing of millennial temperature trends. The long-term cooling trend across the North Atlantic has primarily been attributed to decreasing Northern Hemisphere summer insolation through the Holocene (Ayache et al., 2018; Berger and Loutre, 1991; Berner et al., 2011; Lorenz et al., 2006; Renssen et al., 2005; Wanner et al., 2011), and it is likely that a decrease in the direct heating of the sea surface during summer can explain the observed cooling trend in the Trinity Bay diatom aSST record. During the mid to late-Holocene (7-0 ka BP) June insolation over Newfoundland decreased from 512 to $484 \mathrm{~W} / \mathrm{m}^{2}$ but March insolation increased from 280 to $292 \mathrm{~W} / \mathrm{m}^{2}$ (Figure 6e). Although diatom species bloom through the spring and summer, we suggest that the higher insolation receipt in summer and the larger magnitude change likely had a greater impact on the water temperature and diatom species assemblages than the spring insolation changes.

The long term warming shown by some of the dinocyst records may reflect temperature changes in other seasons. Dinocysts reflect winter/early spring temperature (Solignac et al., 2011) or temperature during different months between early spring and late autumn, depending on the blooming time of individual species (Sheldon et al., 2015). Solignac et al. (2011) suggested that the cooler Newfoundland surface waters indicated by the dinocysts during the HTM were linked to increased export of iceloaded meltwater from the Canadian Arctic, with warming of the surface waters occurring as decreasing Northern Hemisphere temperatures caused reduced glacier melting in the late-Holocene. This scenario for the HTM would allow cold spring SST but warmer surface waters during summer due to the direct summer warming. This is also in agreement with the present day oceanographic setting, where sea ice is primarily transported to Newfoundland with the Labrador Current during the late winter to spring season (Prinsenberg et al., 1997). However, the Northern Hemisphere lower-than-present spring and winter insolation during the HTM (Berger and Loutre, 1991; Figure 6e) may also provide part of the explanation for the warming trend shown by some of the dinocyst records.

Millennial trends in surface and subsurface salinity. The existing dinocyst and benthic foraminiferal reconstructions from core AI07-06G from Trinity Bay and from nearby Bonavista Bay provide information about the past salinity of the surface and deep water that can aid in the interpretation of the millennial trends in aSST (Solignac et al., 2011; Sheldon et al., 2015). Dinocyst species Brigantedinium and I. minutum are strongly anti-correlated with autumn and winter salinity (Solignac et al., 2011); at our study site from Trinity Bay changes in the abundance of these species were small (Sheldon et al., 2015; Figure 6c) but in Bonavista Bay decreasing abundances support that there was a trend from low to high surface salinity through the last $5.7 \mathrm{ka} \mathrm{BP}$ (Solignac et al., 2011; Figure 6c). Furthermore, in Trinity Bay a greater presence of fresh, ice-laden water before 5-6 ka BP is also indicated by more ice-rafted material, as shown by higher concentrations of iron, titanium and potassium (Sheldon et al., 2015; Figure 6d) and a greater presence of Rh. hebetata f. semispina, a diatom species that prefers stratified waters during meltwater pulses. The low salinity in the mid-Holocene has been suggested 


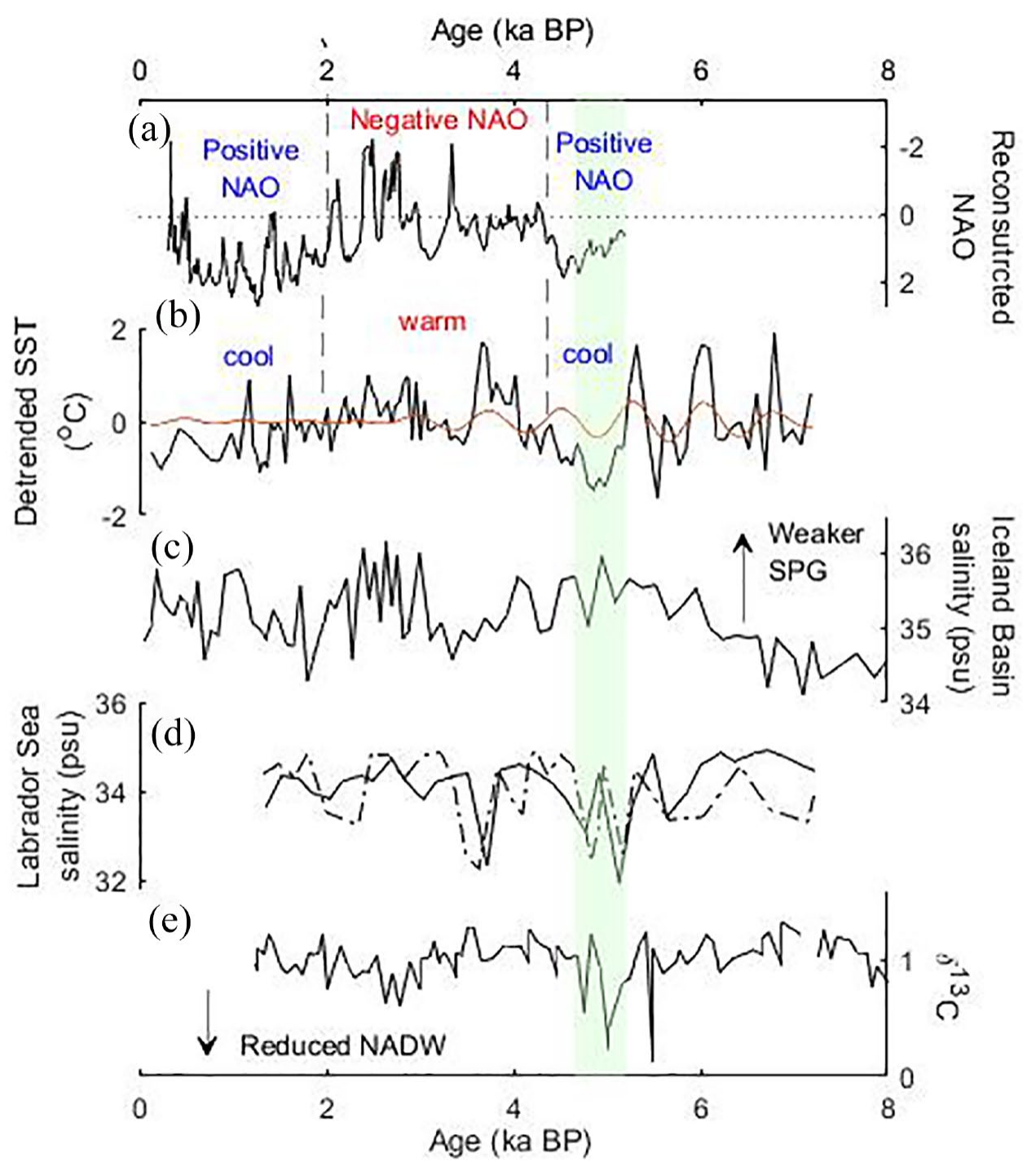

Figure 7. Selected reconstructions reflecting centennial to multi-centennial variability of climatic and oceanographic variables in the northern North Atlantic. (a) NAO reconstruction based on lake hypolimnic anoxia from Greenland (Olsen et al., 20I2). (b) Newfoundland detrended SST reconstruction (this study) and 800-year bandpass filter (orange line). (c) proxy for subpolar gyre strength inferred from the reconstructed near surface salinity of core RAPiD-I2-IK sampled from the Iceland Basin, which was assessed using paired $\mathrm{Mg} / \mathrm{Ca}-\delta^{18} \mathrm{O}$ measurements on planktonic foraminifera Globigerina bulloides (Thornalley et al., 2009). (d) Labrador Sea dinocyst-based salinity reconstructions from core HU90-013-0I3PC from the southwest Greenland Rise (continuous line) and core HU9I-045-094PC from the Orphan Knoll (dashed line) (de Vernal and Hillaire-Marcel, 2006) and E) Reconstruction of $\delta^{13} \mathrm{C}$ from benthic foraminifera, a proxy for NADW from ODP site 980 on the Feni Drift (Oppo et al., 2003). The green shading highlights the period of reduced NADW and colder, fresher surface waters on the Labrador Sea conditions at approximately $5 \mathrm{ka} \mathrm{BP}$, as discussed in sections 5.2 and 5.3 .

as resulting from high meltwater input to the northern North Atlantic, either from the final disintegration of the Laurentide Ice Sheet before 5-6 ka BP (Clark et al., 2000; Occhietti et al., 2011), the decrease in the Greenland Ice Sheet extent prior to 5-6 ka BP (Briner et al., 2016; Hoogakker et al., 2015 and references therein) or from less inflow from saline Irminger Sea Water entering the Labrador Sea (Andersen et al., 2004; Solignac et al., 2006).

The salinity of the deeper (subsurface) water around Newfoundland has been inferred from benthic foraminifera. In Trinity Bay the increasing abundance of Elphidium albiumbilicatum after $5.5 \mathrm{ka}$ BP (Figure 6b) suggests that there was a transition from saline to fresher bottom waters, which has been attributed to a decrease in the inflow of saline Atlantic-derived water transported via the West Greenland Current and LC (Sheldon et al., 2015). The fresher surface water in combination with saline deeper water in Trinity Bay at 7.2-5.5 ka BP may have made the water column more stratified, which is supported by evidence of low bottom water oxygenation at this time (Sheldon et al., 2015), and this would have allowed summer heat to accumulate in the surface waters . Overall, the warm aSST at 7.2-5.2 ka BP in Trinity Bay can be explained by high summer insolation primarily, with marked water column stratification also promoting summer warming of surface waters, while a decrease in summer insolation and increased water mass mixing from the mid to late-Holocene may have contributed to the cooling trend.

\section{Centennial climate variability and the NAO}

Superimposed on the overall cooling trend are $\sim 1-2^{\circ} \mathrm{C}$ centennial-millennial variations in aSST as shown by the linearly detrended record (Figure 7b). The record shows three intervals with generally warmer temperatures between 7.2 and $5.2 \mathrm{ka}$ BP, colder temperatures between 5.2 and $4.0 \mathrm{ka} \mathrm{BP}$, warm temperatures at 4.0-2.1 ka BP interrupted by a cold interval at 3.6-3.1 ka $\mathrm{BP}$, and cooler temperatures after $2.1 \mathrm{ka}$ BP. Factor analysis further suggests that these warmer/colder intervals had an increased/ decreased inflow of water masses associated with the Norwegian Atlantic Current assemblage and, conversely, a decreased/ 
increased influence of waters associated with the Arctic Water assemblage (Figure 4).

A comparison between the detrended aSST record and the longest available NAO reconstruction extending back to $5.2 \mathrm{ka}$ BP (Olsen et al., 2012) supports that the multi-centennial to millennial aSST varied mainly in phase with changes in the reconstructed NAO (Figure 7a). Periods when the reconstructed NAO index was more frequently positive (5.2-4.3 and $2 \mathrm{ka} \mathrm{BP}$ onwards) coincided with lower aSST, while a more neutral-negative NAO index between 4 and $2 \mathrm{ka}$ BP coincided with warmer aSST. A Pearsons correlation between the detrended aSST reconstruction and the NAO reconstruction by Olsen et al. (2012) was conducted, with each record first chronologically aligned by down sampling to a 50 year resolution over the shared interval from $320-5170 \mathrm{ka}$ BP. The correlation shows a negative correlation of $r=-0.38$, which is significant over the $99 \%$ significance level ( $n$ $=98$ ). A similar negative correlation between reconstructed SST on the NE coast of Newfoundland and the Northern Annular Mode (the hemispheric equivalent of the NAO) has been identified in the twentieth century (Sicre et al., 2014). Sicre et al. (2014) also showed that the SST was colder during the Medieval period (ca. 0.95-0.6 ka BP), which was a period when the NAO was positive (Seidenkrantz et al., 2007b, 2008; Olsen et al., 2012; Trouet et al., 2009), which together with the results of this study support a strong long-term influence of NAO-like atmospheric circulation on SST.

The NAO, which is primarily a winter mode of atmospheric circulation, likely altered the SST during summer by influencing the extent of sea ice. Measurements from Station 27 since 1951 show that years with positive NAO in winter have more extensive sea ice as a result of lower winter atmospheric temperatures and greater amounts of ice advected via the Labrador Current, the latter of which is driven by strong northerly winds (Colbourne, 2004; Prinsenberg et al., 1997). The more extensive and persistent spring sea ice cover delays the onset of summer warming, lowering the SST during the summers that follow positive NAO winters (Colbourne, 2004; Prinsenberg et al., 1997).

While the findings support that the patterns of atmospheric circulation associated with the NAO appear to have influenced the SST in Trinity Bay over the mid to late-Holocene, it is possible that other modes of variability were also important. For example, the frequency of atmospheric blocking events, which can cause temperature extremes (Mills et al., 2013; Pfahl and Wernli, 2012), or the AMO (Kerr, 2000), could have varied over multicentennial timescales and influenced the climate and aSST around Newfoundland. A lack of long reconstructions capturing the variability of these patterns of atmospheric and oceanic variability is a current limitation in the assessment of their importance as a control on SST.

The most pronounced cool episode in Trinity Bay at 5.2-4.1 ka BP has also been identified in a dinocyst reconstruction from Bonavista Bay, as fresh and cold surface water conditions were prevalent during the interval from 5.7 to $4 \mathrm{ka} \mathrm{BP}$ (Solignac et al., 2011; Figure 6c). There is also evidence of unusually dry conditions on Newfoundland at 5.2-4 ka BP as reconstructed from peatlands (Amesbury et al., 2013; Blundell et al., 2018). These records support the modern, twentieth century relation between SST and precipitation, as the north coast of Newfoundland has experienced reduced precipitation during periods with colder temperatures, due to drier continental airflows (Banfield and Jacobs, 1998). A record of exotic pollen influx from Placentia Bay, Newfoundland, shows higher influxes at 5.2-4 ka BP indicating that there were stronger westerlies (Jessen et al., 2011), providing supporting evidence that the colder, drier climate was caused by enhanced continental airflows, likely linked with the positive NAO circulation at this time. The following warmer aSST intervals at 4.1-3.6 and 3-2.4 ka BP coincided with warmer atmospheric temperatures on Newfoundland at 4-2 ka BP, as shown by a lake $\delta^{18} \mathrm{O}$ reconstruction (Finkenbinder et al., 2016). Reduced influxes of exotic pollen, and therefore weaker westerly winds, occurred within these intervals at 4-3.2 and 2.8-2.4 ka BP (Jessen et al., 2011), supporting that cold, dry continental airflows became less prevalent, in connection with the neutral-negative NAO circulation patterns.

\section{Oceanographic variability of the Labrador Sea}

The cool event in Trinity Bay at c. 5.2-4.1 ka BP coincided with distinct oceanographic changes elsewhere in the Labrador Sea, including increased sea ice concentrations along the west Greenland coast (Sha et al., 2017), a distinct reduction in surface salinity at c. $5 \mathrm{ka}$ BP in the Labrador Sea and around Newfoundland (Figures 6c and 7d; de Vernal and Hillaire-Marcel, 2006; Solignac et al., 2011), a weaker subpolar gyre (Thornalley et al., 2009) and a sharp, temporary drop in North Atlantic Deep Water (NADW) formation, as indicated by the $\delta^{13} \mathrm{C}$ record from the Feni Drift (Oppo et al., 2003; Figure 7e).

While the surface cooling around Newfoundland and in the Labrador Sea was likely linked to the effects of the predominantly positive NAO index at this time, these conditions may have been magnified by an enhanced supply of cold, fresh water from the Arctic. A strong export of freshwater from the Arctic can be triggered by a persistent positive NAO index, as observed during the 1990's Great Salinity Anomaly (Belkin, 2004) and in model simulations (Condron et al., 2009; Klus et al., 2018). Alternatively, the freshwater may have originated from enhanced melting of the Greenland ice sheet, as indicated by a decreased elevation of ice core sites (GRIP, DYE-3, Camp Century) between 5 and 4 ka BP (Vinther et al., 2009) and a sharp rise in sea level measured in sites in western North America at c. $4.5 \mathrm{ka} \mathrm{BP}$ (Scott and Collins, 1996). Enhanced cold, freshwater from either meltwater or enhanced export from the Arctic, or a combination of both these sources, therefore provides an additional explanation for the particularly cold interval in the Trinity Bay record from 5.2 to $4 \mathrm{ka}$ $\mathrm{BP}$, as additional freshwater would promote sea ice formation and therefore summer cooling.

The lower salinity in the Labrador Sea has also been linked with the weakening of the subpolar gyre strength between 6 and 4 ka BP (Thornalley et al., 2009; Figure 7c), as this would reduce the westward transport of heat and salt from the North Atlantic Drift. On the other hand, the weaker subpolar gyre may have weakened the Labrador Current and reduced the transport of cold water southwards, potentially causing warming around Newfoundland. However, as the aSST decreased in Trinity Bay, the inferred weakening of the Labrador Current does not seem to have had a strong influence on the temperature.

The reduction in NADW formation at $5.2 \mathrm{ka}$ BP (Oppo et al., 2003; Figure 7e) may have been influenced by the temperature and salinity variations in the Labrador Sea. Although the Trinity Bay reconstruction is not situated in the central Labrador Sea where deep water formation occurs, we suggest that SST across the region can be inferred from the AI07-06G record, as a comparison of modern observations from Station 27 on the Newfoundland Shelf and Bravo station in the central Labrador Sea shows similar patterns of SST (Loder and Wang, 2015). The freshening of the Labrador Sea at $\sim 5$ ka BP (de Vernal and Hillaire-Marcel, 2006; Figure $7 \mathrm{~d}$ ) and the cooler temperatures inferred by the Trinity Bay reconstruction would have had an opposing impact on the surface water density. As the evidence supports that NADW formation decreased (Oppo et al., 2003; Figure 7e), it may be concluded that salinity significantly reduced the water density and had a greater impact on convection than temperature at this point.

During the late-Holocene as sources of meltwater declined and salinity of the Labrador Sea stabilised (de Vernal and 
Hillaire-Marcel, 2006) the subpolar gyre was instead mainly driven by wind stress rather than salinity (Thornalley et al., 2009). For example, the negative NAO between 3 and 2 ka BP is likely to have weakened the westerly winds over the Atlantic causing the weaker subpolar gyre circulation (Figure 7c), which may have increased the aSST in Trinity Bay as a weaker subpolar gyre would transport less cold water and ice southwards to Newfoundland. Subpolar gyre strength and the southward transport of heat to Newfoundland therefore provides an additional mechanism through which the NAO may have altered aSST during the late-Holocene.

\section{Solar Forcing of multi-centennial aSST variability}

Solar variability is often discussed as a driver of centennial-millennial timescale climate variability, for example solar variability has been linked to changes in atmospheric circulation that alter North Atlantic ocean circulation (Moffa-Sánchez et al., 2014; Swingedouw et al., 2011). A significant 800 -year cycle in the Trinity Bay record (Figure 5) was dominant prior to $5 \mathrm{ka} \mathrm{BP}$, as shown by the bandpass filter results (Figure 7b), and was associated with three distinct centennial aSST warming events at c. 6.8, 6 and $5.3 \mathrm{ka} \mathrm{BP}$ in Trinity Bay and the later warming at $4 \mathrm{ka}$ BP. The origin of this 800 -yr cycle is not certain, but may be an 800 -yr expression of the $\sim 200$ year De Vries/Suess cycle. On the eastern periphery of the North Atlantic in Ireland, a 7500-year long record of bog tree populations reflecting changes in surface moisture has also shown an 800 year cycle, which conversely appeared at $5 \mathrm{ka}$ BP (Turney et al., 2005). Turney et al. (2005) did not find a linear connection with solar variability but suggested that the climate system responded non-linearly to solar forcing, with southward excursions of polar water in the North Atlantic and changes in the latitude and intensity of atmospheric circulation, both of which would have potentially also altered the climate in the northwest Atlantic. The timing of the disappearance of the 800-year cycle at $5 \mathrm{ka}$ BP in the Trinity Bay record may have been linked to global changes in the climate system, as spectral analysis of palaeoclimate records globally identifies that at $5 \mathrm{ka}$ BP many cycles of varying lengths appeared or disappeared (Debret et al., 2009; Wirtz et al., 2010).

\section{Conclusion}

A diatom-based aSST reconstruction from core AI07-06G, retrieved from Trinity Bay, Newfoundland, Canada, spans the interval 7.2-0.1 ka BP. The record shows a clear long-term cooling trend of $0.4^{\circ} \mathrm{C} / 1000$ years; a warm HTM with temperatures of $\sim 7^{\circ} \mathrm{C}$ ended at $5.2 \mathrm{ka} \mathrm{BP}$ with subsequent cooling to temperatures of $\sim 4^{\circ} \mathrm{C}$ during the last 1200 years when sea ice presence increased. Superimposed on this trend are multi-centennial variations in aSST of $1-2^{\circ} \mathrm{C}$, with warmer temperatures at c. 6.8 , 6.1-5.9, 5.4-5.2 and 4.1-3.6 ka BP and colder temperatures at $\mathrm{c}$. $5.5,5.2-4.1,3.6-3.1,1.3$ and $1-0 \mathrm{ka} \mathrm{BP}$.

The long-term cooling trend can likely be attributed to declining Northern Hemisphere summer insolation and decreasing stratification of the water column with changing salinity. The higher stratification in the HTM presumably resulted from increased meltwater influx to the region before $5 \mathrm{ka} \mathrm{BP}$ from the melting of the remnant Laurentide Ice Sheet and from the Greenland Ice Sheet.

Comparison of the multi-centennial aSST variations with an NAO reconstruction (Olsen et al., 2012) supports that the NAO had a pivotal role in driving aSST fluctuations. This reflects the strong modern negative correlation between the NAO and temperature across the northwest Atlantic, with winter atmospheric circulation moderating summer temperatures through changes in the duration and extent of sea ice cover.
The prolonged cold interval on Newfoundland at 5.2-4.1 ka BP had a dry climate and strong westerly winds (Amesbury et al., 2013; Jessen et al., 2011), consistent with enhanced continental airflow during a positive NAO. The aSST during this period may have been further lowered by an enhanced supply of cold, fresh water around Newfoundland and across the Labrador Sea, from either a greater export of freshwater from the Arctic or enhanced meltwater from Greenland, or a combination of both. This freshening was potentially amplified by a weakening of the subpolar gyre and a reduced westward transport of saline water from the North Atlantic Drift. The cold and fresh surface water conditions coincided with a sharp reduction in North Atlantic Deep Water formation (Oppo et al., 2003), suggesting that convection may have been prevented by the surface water freshening. Although further research is needed to confirm the temperature patterns in the central Labrador Sea and the convection history of this area, the results imply that excessive freshwater input in the North Atlantic can significantly reduce deep convection, whereas strong warming of the ocean surface has less of an impact.

The period from 4 to $2 \mathrm{ka} \mathrm{BP}$ had warm temperatures on Newfoundland coinciding with evidence of weaker westerly airflow, consistent with a dominant negative NAO circulation pattern. Weakening of the subpolar gyre at $\sim 4$ and 3-2 ka BP (Thornalley et al., 2009) may have amplified the warming in Trinity Bay by reducing the southward transport of cool, ice-laden water via the Labrador Current as previously suggested by Solignac et al. (2011).

Finally, spectral analysis showed a dominant $\sim 800$ year cycle through the record, which was particularly pronounced between 7.2 and $5 \mathrm{ka} \mathrm{BP}$ when three peaks in aSST occurred at $\sim 800$ year intervals. We speculate that this was an expression of the 200 -year de Vries solar cycle.

\section{Acknowledgements}

We would like to thank the captain and crew of RV 'Akademik Ioffe', as well as the entire scientific party for their help during the research cruise.

\section{Funding}

The author(s) disclosed receipt of the following financial support for the research, authorship, and/or publication of this article: The cruise was funded by the Danish Council for Independent Research, Natural Science (Project No. 272-06-0604/FNU) and carried out within the Danish-Russian collaboration project 'Joint paleoceanographic investigations in the Labrador Sea region'. The work was partly funded by the Kone Foundation with additional support from the Independent Research Fund Denmark (grant no. 7014-00113B/FNU, G-Ice).

\section{ORCID iDs}

Lisa C Orme (iD https://orcid.org/0000-0003-0210-9264

Marit-Solveig Seidenkrantz (iD https://orcid.org/0000-0002-1973 $-5969$

\section{Supplemental material}

Supplemental material for this article is available online.

\section{Bibliography}

Agnew T (1993) Simultaneous winter sea-ice and atmospheric circulation anomaly patterns. Atmosphere-Ocean 31(2): 259-280.

Amesbury MJ, Mallon G, Charman DJ et al. (2013) Statistical testing of a new testate amoeba-based transfer function for water-table depth reconstruction on ombrotrophic peatlands in north-eastern Canada and Maine, United States. Journal of Quaternary Science 28: 27-39. 
Andersen C, Koç N, Jennings A et al. (2004) Nonuniform response of the major surface currents in the Nordic Seas to insolation forcing: Implications for the Holocene climate variability. Paleoceanography 19(2): 1-16.

Ayache M, Swingedouw D, Mary Y et al. (2018). Multi-centennial variability of the AMOC over the Holocene : A new reconstruction based on multiple proxy-derived SST records. Global and Planetary Change 170: 172-189.

Bamber J, Van Den Broeke M, Ettema J et al. (2012). Recent large increases in freshwater fluxes from Greenland into the North Atlantic. Geophysical Research Letters 39(19): 8-11.

Banfield CE and Jacobs JD (1998) Regional patterns of temperature and precipitation for Newfoundland and Labrador during the past. The Canadian Geographer 9(4): 354-364.

Belkin IM (2004) Propogation of the "Great Salinity Anomaly" of the 1990s around the northern North Atlantic. Geophysical Research Letters 31(8): 4-7.

Belkin IM, Levitus S, Antonov J et al. (1998). "Great salinity anomalies" in the North Atlantic. Progress in Oceanography 41(1): 1-68.

Bendat JS and Piersol AG (1986) Decomposition of wave forces into linear and non-linear components. Journal of Sound and Vibration 106(3): 391-408.

Berger A and Loutre M-F (1991) Insolation values for the climate of the last 10 million years. Quaternary Science Reviews 10(4): 297-317.

Berner KS, Ko N, Godtliebsen F et al. (2011) Holocene climate variability of the Norwegian Atlantic Current during high and low solar insolation forcing. Paleoceanography 26(2): $1-15$.

Berner KS, Koç N, Divine D et al. (2008) A decadal-scale Holocene sea surface temperature record from the subpolar North Atlantic constructed using diatoms and statistics and its relation to other climate parameters. Paleoceanography 23(2): 1-15.

Birks H (1998) Numerical tools in palaeolimnology-progress, potentialities, and problems. Journal of Paleolimnology 20: 307-332.

Blundell A, Hughes PDM and Chambers FM (2018) An 8000year multi-proxy peat-based palaeoclimate record from Newfoundland: Evidence of coherent changes in bog surface wetness and ocean circulation. The Holocene 28(5): 791-805.

Böning CW, Behrens E, Biastoch A et al. (2016) Emerging impact of Greenland meltwater on deepwater formation in the North Atlantic Ocean. Nature Geoscience 9: 523-528.

Briner JP, McKay NP, Axford Y et al. (2016). Holocene climate change in Arctic Canada and Greenland. Quaternary Science Reviews 147: 340-364.

Brown MacPherson J (1995). A 6 ka BP reconstruction for the island of Newfoundland from a synthesis of Holocene lakesediment pollen records. Géographie Physique et Quaternaire 49(1): 163-182.

Canadian Ice Service (2020) 30-year Ice Atlas. Available at: https:// iceweb1.cis.ec.gc.ca/30Atlas/page1.xhtml?region=WA\& lang=en (accessed 02 June 2020).

Clark CD, Knight JK and Gray JT (2000) Geomorphological reconstruction of the Labrador Sector of the Laurentide Ice Sheet. Quaternary Science Reviews 19(13): 1343-1366.

Colbourne EB (2004) Decadal changes in the ocean climate in newfoundland and labrador waters from the 1950s to the 1990s. Journal of Northwest Atlantic Fishery Science 34: 43-61.

Condron A, Winsor P, Hill C et al. (2009) Simulated response of the Arctic freshwater budget to extreme NAO wind forcing. Journal of Climate 22(9): 2422-2437.

de Vernal A and Hillaire-Marcel C (2006) Provincialism in trends and high frequency changes in the northwest North Atlantic during the Holocene. Global and Planetary Change 54(3-4): 263-290.
Debret M, Sebag D, Crosta X et al. (2009). Evidence from wavelet analysis for a mid-Holocene transition in global climate forcing. Quaternary Science Reviews 28(25-26): 2675-2688.

Deser C, Holland M, Reverdin G et al. (2002) Decadal variations in Labrador Sea ice cover and North Atlantic sea surface temperatures. Journal of Geophysical Research: Oceans 107(C5): 3-1-3-12.

Dickson R, Lazier J, Meincke J et al. (1996) Long-term coordinated changes in the convective activity of the North Atlantic. Progress in Oceanography 38(3): 241-295.

Drinkwater KF (1996) Atmospheric and oceanic variability in the Northwest Atlantic during the $1980 \mathrm{~s}$ and early $1990 \mathrm{~s}$. Journal of Northwest Atlantic Fishery Science 18: 77-97.

Finkenbinder MS, Abbott MB and Steinman BA (2016) Holocene climate change in Newfoundland reconstructed using oxygen isotope analysis of lake sediment cores. Global and Planetary Change 143: 251-261.

Fisheries and Oceans Canada (2012) Ice Navigation in Canadian Waters. Ontario: Icebreaking Programme.

Flatau MK, Talley L and Niiler PP (2003) The North Atlantic Oscillation, surface current velocities, and SST changes in the subpolar North Atlantic. Journal of Climate 16(14): $2355-2369$.

Gajewski K (2015). Quantitative reconstruction of Holocene temperatures across the Canadian Arctic and Greenland. Global and Planetary Change 128: 14-23.

Haak H, Jungclaus J, Mikolajewicz U et al. (2003) Formation and propagation of great salinity anomalies. Geophysical Research Letters 30(9): 1473.

Häkkinen S, Rhines PB and Worthen DL (2011) Atmospheric blocking and atlantic multidecadal ocean variability supplemental online material. Science 334: 655-659.

Hammer Ø, Harper DAT and Ryan PD (2001) PAST: Paleontological statistics software package for education and data analysis. Palaeontologia Electronica 4(1): 9.

Han G, Ohashi K, Chen N et al. (2010) Decline and partial rebound of the Labrador Current 1993-2004: Monitoring ocean currents from altimetric and conductivity-temperaturedepth data. Journal of Geophysical Research Atmospheres 115(12): 1-10.

Hoogakker BAA, Mccave IN, Elderfield H et al. (2015) Holocene climate variability in the Labrador sea. Journal of the Geological Society 172: 272-277.

Hurrell JW (1995) Decadal trends in the North Atlantic Oscillation: Regional temperatures and precipitation. Science 269(5224): 676-679.

Hurrell JW and Deser C (2010) North atlantic climate variability: The role of the north atlantic oscillation. Journal of Marine Systems 79: 231-244.

Hurrell JW and Van Loon H (1997) Decadal variations in climate associated with the North Atlantic Oscillation. Climatic Change 36(3-4): 301-326.

Imbrie J and Kipp NG (1971) A new micropalaeontological method for quantitative paleoclimatology: Application to a late Pleistocene Caribbean core. In: Turekian KK (ed.) The Late Cenozoic Glacial Ages. New Haven, CT: Yale University Press, pp. 77-131.

Jessen CA, Solignac S, Nørgaard-Pedersen N et al. (2011) Exotic pollen as an indicator of variable atmospheric circulation over the Labrador Sea region during the mid to late-Holocene. Journal of Quaternary Science 26(3): 286-296.

Jiang H, Eiríksson J, Schulz M et al. (2005) Evidence for solar forcing of sea-surface temperature on the North Icelandic Shelf during the late-Holocene. Geology 33(1): 73-76.

Keigwin LD, Sachs JP, Rosenthal Y et al. (2005) The 8200 year B.P. event in the slope water system, western subpolar North Atlantic. Paleoceanography and Paleoclimatology 20(2): 1-14. 
Kerr RA (2000) A north atlantic climate pacemaker for the centuries. Science 288: 1984-1985.

Khatiwala S, Schlosser P and Visbeck M (2002) Rates and mechanisms of water mass transformation in the labrador sea as inferred from tracer observations. Journal of Physical Oceanography 32: 666-686.

Klus A, Prange M, Varma V et al. (2018) Abrupt cold events in the North Atlantic Ocean in a transient Holocene simulation. Climate of the Past 14(8): 1165-1178.

Knudsen MF, Seidenkrantz M-S, Jacobsen BH et al. (2011) Tracking the atlantic multidecadal oscillation through the last 8,000 years. Nature Communications 2:178.

Knudsen MF, Jacobsen BH, Seidenkrantz M-S et al. (2014) Evidence for external forcing of the Atlantic Multidecadal Oscillation since the termination of the little ice age. Nature Communications 5:3323.

Koç N, Jansen E and Haflidason H (1993) Paleoceanographic reconstructions of surface ocean conditions in the Greenland, Iceland and Norwegian seas through the last $14 \mathrm{ka}$ based on diatoms. Quaternary Science Reviews 12(2): 115-140.

Koç Karpuz N and Schrader H (1990) Surface sediment diatom distribution and Holocene paleotemperature variations in the Greenland, Iceland and Norwegian Sea. Paleoceanography and Paleoclimatology 5(4): 557-580.

Kolstad EW, Bracegirdle TJ and Seierstad IA (2009) Marine coldair outbreaks in the North Atlantic: Temporal distribution and associations with large-scale atmospheric circulation. Climate Dynamics 33(2-3): 187-197.

Loder JW and Wang Z (2015) Trends and variability of sea surface temperature in the northwest atlantic from three historical gridded datasets trends and variability of sea surface temperature in the northwest Atlantic from three historical gridded datasets. Atmosphere-Ocean 1: 1-19.

Lorenz SJ, Kim JH, Rimbu N et al. (2006) Orbitally driven insolation forcing on Holocene climate trends: Evidence from alkenone data and climate modeling. Paleoceanography 21(1): $1-14$.

McCarthy GD, Haigh ID, Hirschi JJ-M et al. (2015) Ocean impact on decadal Atlantic climate variability revealed by sea-level observations. Nature 521: 508-510.

Miettinen A (2018) Diatoms in Arctic regions: potential tools to decipher environmental changes. Polar Science 18: 220-226.

Miettinen A, Divine DV, Husum K et al. (2015) Exceptional ocean surface conditions on the SE Greenland shelf during the Medieval Climate Anomaly. Paleoceanography 30(12): $1657-1674$

Mills KE, Pershing AJ, Brown CJ et al. (2013) Fisheries management in a changing climate: Lessons from the 2012 ocean heat wave in the Northwest Atlantic. Oceanography 26(2): 191-195.

Moffa-Sánchez P, Born A, Hall IR et al. (2014) Solar forcing of north atlantic surface temperature and salinity over the past millennium. Nature Geoscience 7 (2014): 275-278.

Moros M, Lloyd JM, Perner K et al. (2016) Surface and subsurface multi-proxy reconstruction of middle to late-holocene palaeoceanographic changes in disko bugt, West Greenland. Quaternary Science Reviews 132: 146-160.

Myers RA, Akenhead SA and Drinkwater K (1990) The influence of Hudson Bay runoff and ice-melt on the salinity of the inner Newfoundland Shelf. Atmosphere-Ocean 28(2): 241-256.

Occhietti S, Parent M, Lajeunesse P et al. (2011) Late pleistocene-early holocene decay of the laurentide ice sheet in québec-labrador. Developments in Quaternary Sciences 15: 601-630.

Oksman M, Juggins S, Miettinen A et al. (2019). The biogeography and ecology of common diatom species in the northern
North Atlantic, and their implications for paleoceanographic reconstructions. Marine Micropaleontology 148: 1-28.

Oksman M, Weckström K, Miettinen A et al. (2017) Younger dryas ice margin retreat triggered by ocean surface warming in central-eastern Baffin Bay. Nature Communications 8: 1017.

Olsen J, Anderson NJ and Knudsen MF (2012) Variability of the north atlantic oscillation over the past 5,200 years. Nature Geoscience 5(11): 808-812.

Oppo DW, McManus JF and Cullen JL (2003) Palaeo-oceanography: Deepwater variability in the Holocene epoch. Nature 422(6929): 277-278.

Orme LC, Miettinen A, Divine D et al. (2018) Subpolar north atlantic sea surface temperature since $6 \mathrm{Ka}$ BP: Indications of anomalous ocean-atmosphere interactions at 4-2 Ka BP. Quaternary Science Reviews 194: 128-142.

Pearce C, Weckström K, Sha L et al. (2014) The Holocene marine diatom flora of Eastern Newfoundland bays. Diatom Research 29 (4): 441-454.

Petrie B, Loder JW, Akenhead S et al. (1991) Temperature and salinity variability on the eastern Newfoundland shelf: The annual harmonic. Atmosphere-Ocean 29(1): 14-36.

Petrie B and Isenor A (1985) The near-surface circulation and exchange in the Newfoundland Grand Banks region. Atmosphere-Ocean 23(3): 209-227.

Pfahl S and Wernli H (2012) Quantifying the relevance of atmospheric blocking for Co-located temperature extremes in the northern hemisphere on (Sub-) daily time scales. Geophysical Research Letters 39: L12807.

Prinsenberg SJ, Peterson IK, Narayanan S et al. (1997) Interaction between atmosphere, ice cover, and ocean off Labrador and Newfoundland from 1962 to 1992. Canadian Journal of Fisheries and Aquatic Sciences 54(S1): 30-39.

Ramsey CB (2008) Deposition models for chronological records. Quaternary Science Reviews 27(1-2): 42-60.

Reimer PJ, Bard E, Bayliss A et al. (2013). IntCal13 and Marine13 radiocarbon age calibration curves $0-50,000$ years cal BP. Radiocarbon 55(4): 1869-1887.

Ren J, Jiang H, Seidenkrantz M-S et al. (2009) A diatom-based reconstruction of Early Holocene hydrographic and climatic change in a southwest Greenland fjord. Marine Micropaleontology 70(3-4): 166-176.

Renssen H, Goosse H and Fichefet T (2005) Contrasting trends in north Atlantic deep-water formation in the Labrador Sea and Nordic Seas during the Holocene. Geophysical Research Letters 32(8): 1-4.

Robson J, Ortega P and Sutton R (2016) A reversal of climatic trends in the North Atlantic since 2005. Nature Geoscience 9(7): 513.

Sachs JP (2007) Cooling of northwest Atlantic slope waters during the Holocene. Geophysical Research Letters 34(3): $1-4$.

Schrader H and Gersonde R (1978) Diatoms and silicoflagellates. In Zachariasse et al. microplaeontological counting methods and techniques-an excercise on an eight metres section of the lower pliocene of capo rossello. Sicily Utrecht Micropaleontological Bulletins 17: 129-176.

Schulz M and Mudelsee M (2002) REDFIT: Estimating red-noise spectra directly from unevenly spaced paleoclimatic time series. Computers and Geosciences 28(3): 421-426.

Scott DB and Collins ES (1996) Late mid-Holocene sea-level oscillation: A possible cause. Quaternary Science Reviews 15(8-9): 851-856.

Seidenkrantz M-S, Kuijpers A and Troelstra S (2007a) Joint paleoceanographic investigations in the Labrador Sea, cruise report 'Akademik Ioffe', September 23-28 2007.

Seidenkrantz M-S, Sulsbrück H, Kuijpers A et al. (2007b) Hydrography and climate of the last 4400 years in a SW Greenland 
fjord: Implications for Labrador Sea palaeoceanography. The Holocene 17(3): 387-401.

Seidenkrantz M-S, Roncaglia L, Fischel A et al. (2008) Variable North Atlantic climate seesaw patterns documented by a lateHolocene marine record from Disko Bugt, West Greenland. Marine Micropalaeontology 68: 66-83.

Sha L, Jiang H and Knudsen KL (2012) Diatom evidence of climatic change in Holsteinsborg Dyb, west of Greenland, during the last 1200 years. The Holocene 22(3): 347-358.

Sha L, Jiang H, Seidenkrantz M-S et al. (2016) Solar forcing as an important trigger for West Greenland sea-ice variability over the last millennium. Quaternary Science Reviews 131: 148-156.

Sha L, Jiang H, Seidenkrantz M-S et al. (2017). A record of Holocene sea-ice variability off West Greenland and its potential forcing factors. Palaeogeography, Palaeoclimatology, Palaeoecology 475: 115-124.

Sheldon CM, Seidenkrantz M-S, Pearce C et al. (2016) Holocene oceanographic changes in SW Labrador Sea, off Newfoundland. The Holocene 26(2): 274-289.

Sheldon CM, Seidenkrantz M-S, Frandsen P et al. (2015) Variable influx of West Greenland current water. Arktos 1(1): 1-19.

Sicre M, Weckström K, Seidenkrantz M-S et al. (2014) Labrador current variability over the last 2000 years. Earth and Planetary Science Letters 400: 26-32.

Seidov D, Baranova OK, Boyer T et al. (2016) Northwest Atlantic Regional Ocean Climatology. NOAA Atlas NESDIS 80, Tech. Ed.: A.V. Mishonov. Silver Spring, MD. doi:10.7289/ V5/ATLAS-NESDIS-80

Solignac S, Giraudeau J and De Vernal A (2006) Holocene sea surface conditions in the western north atlantic: Spatial and temporal heterogeneities. Paleoceanography 21: 1-16.

Solignac S, Seidenkrantz M-S, Jessen C et al. (2011) Late-Holocene sea-surface conditions offshore Newfoundland based on dinoflagellate cysts. The Holocene 21(4): 539-552.

Sun C, Li J and Jin F-F (2015) A delayed oscillator model for the quasi-periodic multidecadal variability of the NAO. Climate Dynamics 45: 2083-99.

Swingedouw D, Terray L, Cassou C et al. (2011) Natural forcing of climate during the last millennium: Fingerprint of solar variability. Climate Dynamics 36: 1349-1364.

Taboada FG and Anadón R (2012) Patterns of change in sea surface temperature in the North Atlantic during the last three decades: Beyond mean trends. Climatic Change 115(2): 419-431.

ter Braak CJF and Juggins S (1993) Weighted averaging partial least squares regression (WA-PLS): An improved method for reconstructing environmental variables from species assemblages. Hydrobiologia 269(1): 485-502.

Thornalley DJR, Elderfield H and McCave IN (2009) Holocene oscillations in temperature and salinity of the surface subpolar North Atlantic. Nature 457: 711-714.

Torrence C and Compo GP (1998) A practical guide to wavelet analysis. Bulletin of the American Meteorological Society 79: 61-78.

Trachsel M and Telford RJ (2016) Estimating unbiased transferfunction performances in spatially structured environments. Climate of the Past 12(5): 1215-1223.

Trenberth KE and Shea DJ (2006) Atlantic hurricanes and natural variability in 2005. Geophysical Research Letters 33: L12704.

Trouet V, Esper J, Graham NE et al. (2009) Persistent positive north atlantic oscillation mode dominated the medieval climate anomaly. Science 324(5923): 78-80.

Turney C, Baillie M, Clemens S et al. (2005) Testing solar forcing of pervasive Holocene climate cycles. Journal of Quaternary Science 20: 511-518.

Umoh JU, Loder JW and Petrie B (1995) The role of air-sea heat fluxes in annual and interannual ocean temperature variability on the eastern newfoundland shelf. Atmosphere-Ocean 33(3): 531-568.

Viau AE, Gajewski K, Sawada MC et al. (2006). Millennial-scale temperature variations in North America during the Holocene. Journal of Geophysical Research Atmospheres 111(9): 1-12.

Vinther BM, Buchardt SL, Clausen HB et al. (2009) Holocene thinning of the Greenland ice sheet. Nature 461(7262): 385.

Von Quillfeldt CH (2000) Common diatom species in arctic spring blooms: Their distribution and abundance. Botanica Marina 43: 499-516.

Wanner H, Solomina O, Grosjean M et al. (2011) Structure and origin of Holocene cold events. Quaternary Science Reviews 30(21-22): 3109-3123.

Wirtz KW, Lohmann G, Bernhardt K et al. (2010) Mid-Holocene regional reorganization of climate variability: Analyses of proxy data in the frequency domain. Palaeogeography, Palaeoclimatology, Palaeoecology 298(3-4): 189-200.

Yang Q, Dixon TH, Myers PG et al. (2016) Recent increases in arctic freshwater flux affects Labrador Sea convection and Atlantic overturning circulation. Nature Communications 7: 10525.

Yao T (1986) The response of currents in Trinity Bay, Newfoundland, to local wind forcing. Atmosphere-Ocean 24(3): $235-252$. 